\title{
CLINICAL MANIFESTATION OF BMI, TLC, ALBUMIN AND CD4 AFTER PROVISION OF SNAKEHEAD NUGGET AND COLORED FRUIT JUICE TO PEOPLE WITH HIV
}

\author{
Ngena Ria ${ }^{1}$, Ginta Siahaan ${ }^{2 *}$, Zuraidah Nasution ${ }^{3}$, Hanna Sriyanti Saragih ${ }^{4}$ \\ ${ }^{1}$ Department of Dental Hygiene, Poltekkes Kemenkes Medan, Indonesia \\ ${ }^{2,3}$ Department of Nutrition, Poltekkes Kemenkes Medan, Indonesia \\ ${ }^{4}$ Department of Midwifery, Poltekkes Kemenkes Medan, Indonesia \\ *E-mail: ginzsiahaan@gmail.com
}

\begin{abstract}
Snakehead fish has high content of zinc and albumin, it can be given to people with immune disorder. Snakehead fish can be made into various kind of food product that are high in nutrients, have aesthetic value, and taste like nugget. The effectiveness of zinc and albumin function can work optimally when the consumption is combined with food ingredient that are high in bioactive substances such as lycopene, anthocyanin, flavonoid, karetonoid, bromelain, papain and quercetin. The purpose of this study was to analyze the effect of snakehead nugget administration and colored fruit juices simultaneously on clinical manifestation, BMI, TLC, albumin and CD4 value in PLHIV at HIV/ AIDS Rehabilitation Center in Medan. The design of research was quasy experimental with pre and post test design. The subjects was 40 people who lived at HIV/AIDS Rehabilitation Center in Medan and given snakehead fish nugget and colored fruit juice for 24 days. The data analysis used dependent T-test, after data normality test had previously been carried out. There was effect before and after administration of snakehead fish nuggets and colored fruit juice on clinical manifestation, BMI, TLC and CD4 levels with $\mathrm{p}$ value $<0.05$. It is necessary to provide treatment in longer term as preventive measure for the emergence of various clinical manifestations as well as to increase BMI, TLC, albumin and CD4 in PLHIV at HIV/AIDS Rehabilitation Center in Medan.
\end{abstract}

Keywords: HIV, snakehead fish, colored fruit extract, clinical manifestation

\section{INTRODUCTION}

Acquired Immune Deficiency Syndrome (AIDS) is a collection of symptoms caused by the Human Immunodeficiency Virus (HIV). This virus damages human immune system which causes a decrease or loss of immunity (Kemenkes, 2010). It is marked the decreasing number of TLC and CD4 among people living with HIV (PLHIV) then followed by symptoms like persistent diarrhoea, drastic weight loss without knowing the reason, fever and muscle ache (Pitri, 2013). As a result, PLHIV will experience nutritional status disorders, which is marked by a low BMI score (Pusdiklat, 2014; Brennan, 2019). Excessive catabolism occurs followed by lower levels of albumin in the blood. (Yuniarti, 2013; Adiningsih, 2017).

The state of malnutrition will worsen the nutritional status of PLHIV as assessed by lower body mass index. The causes are multifactorial, particularly due to lack of food intake, impaired absorption and metabolism of nutrients, emergence of opportunistic infections, marked by a decrease in the total immunity response of cluster of differentiation 4 and total lymphocyte count (Anderson, 2017). Macronutrients such as proteins, which is part of antibody-forming substances, also play a role in building cells damaged by opportunistic infection. Other nutrient such as vitamin $\mathrm{C}$ can suppress the formation of free radicals and can also increase the resistance of PLHIV (Almatsier, 2018).

Snakehead fish is a food that has been researched by many people. It can be made into various kind of food products that have high aesthetic value and taste but still contain nutrient, one of which is snakehead fish nugget with the addition of red bean. In $100 \mathrm{~g}$ of snakehead fish nugget contain $2.28 \mathrm{~g}$ of albumin, $18.66 \mathrm{~g}$ of protein, and $6.70 \mathrm{mg}$ of zinc. 100 gram of snakehead fish nugget was given every day. The results of Pettalolo research (2015), zinc and albumin content in snakehead fish extract was proven to increase the amount of TLC in PLHIV. 
The effectiveness of snakehead fish nuggets should be combined with food containing vitamin $\mathrm{C}$ and bioactive substances derived from natural ingredient which can be obtained from the content of colorful fruit and vegetable. These colored fruit and vegetable are used as a juice. These colored fruit juice contain bioactive substances in the form of Vitamin C, lycopene, anthocyanin, flavonoid, karetonoid, beta-carotene, bromelain, papain and quercetin. Colored fruit juice is given $250 \mathrm{~mL}$ together with snakehead fish nugget (Winarti, 2017). The purpose of this study was analyze effect of snakehead nugget distribution and colored fruit juice on clinical manifestations, BMI, TLC, albumin and CD4 in PLHIV at HIV/ AIDS Rehabilitation Center in Medan.

\section{METHOD}

Design of this research was quasi experimental study with one group pre and post test design (Rahmat, 2015). The research was conducted at HIV/AIDS Rehabilitation Center in Medan. The population in this study were all PLHIV at HIV/AIDS Rehabilitation Center in Medan. Total Sampling was done to the entire population that amount of 40 respondents.

The intervention was given for 24 consecutive days directly by researcher who was assisted by 7 enumerators who were already briefed. Duration of intervention phased on albumin half-life is 19-24 days. Respondent were given 2 nuggets $(100 \mathrm{~g})$ of snakehead fish a day (Supariasa, 2016; Prastowo, 2016). Snakehead fish nuggets are made in Food Technology Laboratory in Department of Nutrition, Poltekkes Kemenkes Medan. The ingredients of this nuggets were snakehead fish, carrots, red beans, wheat flour, eggs, shallots, garlic, pepper,

Table 1. Nutrition Content of 100 grams Snakehead Fish Nuggets

\begin{tabular}{cc}
\hline Nutrient & Content \\
\hline Albumin & $2.28 \mathrm{gr}$ \\
Calcium & $81.59 \mathrm{gr}$ \\
Iron & $2.95 \mathrm{mg}$ \\
Carbohydrates & $9.12 \mathrm{gr}$ \\
Fat & $13.76 \mathrm{gr}$ \\
Protein & $18.66 \mathrm{gr}$ \\
Zinc & $6.70 \mathrm{mg}$ \\
\hline
\end{tabular}

and salt. Nutrition content of 100 grams snakehead fish nuggets can be seen in table 1 .

The examination of proximate test regarding the nutrient content was carried out in MIPA laboratory of Universitas Brawijaya, by sending samples of snakehead fish nuggets in January 2019. Colored fruit juice is selected every day for one colored fruit/vegetable as much as $200 \mathrm{~g}$ by adding enough water and $18 \mathrm{~g}$ sugar then blended and extracted to get one glass of colored fruit juice as much as $250 \mathrm{~mL}$. Colored fruit juice do not prioritize nutritional content, but focus on function of bioactive substances contained in colored fruits and vegetables, such as, guava, dragon fruits, carrot, pineapple, red and yellow watermelon, star fruit, papaya, tomato, cucumber and orange.

BMI data were obtained by measuring body weight using a digital scale with an accuracy of $0.01 \mathrm{~kg}$, meanwhile body height using microtoise with an accuracy of $0.1 \mathrm{~cm}$ then interpreted the BMI results obtained into the BMI standard table according to (Negara et al., 2015). Blood sampling for blood biochemical examination was carried out twice during study, before and after treatment administration. Blood was drawn using $3 \mathrm{~mL}$ syringe from left arm, the work was carried out by health analyst and then checked in Pathology Laboratory. TLC data is obtained from examination of the type of leucocytes and total leucocytes on routine blood tests with cyanmethemoglobin method using spectofotometry tool. CD4 data is done using Flow Cytometri method. Blood albumin data were examined by BCG method (Brom Cresol Green).

Clinical manifestation data were collected through direct interviews with the respondents and direct observation using clinical manifestation form. The questionnaire contains 16 items of clinical manifestation symptoms, each of it has clinical symptom based on clinical manifestation form, each item of symptom worth 1 score. Data was previously tested for data normality with Kolmogorov Smirnov test and continued with dependent $T$ test (paired). The study was conducted after got the ethics permission from the research ethics commission at Poltekkes Kemenkes Medan with no: 044 / KEPK / POLTEKKES KEMENKES MEDAN / 2019. 


\section{RESULTS AND DISCUSSION}

The 21-30 year old group was the largest respondents as much as 19 people $(47.5 \%)$, with the youngest being 20 years old and the oldest 54 years old. The most of respondents is male $90 \%$ (36 people). The percentage of respondent education is mostly having high school as many 30 people $(75 \%)$. Respondent characteristics can be seen in table 2 .

For the average value of TLC, albumin, CD4, clinical manifestations and BMI before and after treatment showed in Table 3 below:

Table 2. Distribution of Respondent Characteristics.

\begin{tabular}{cccc}
\hline \multirow{2}{*}{ Respondent Characteristics } & \multicolumn{2}{c}{ Total } \\
\cline { 2 - 4 } & & $\mathbf{n}$ & $\mathbf{\%}$ \\
\hline \multirow{4}{*}{ Age } & $11-20$ y.o & 2 & 5 \\
& $21-30$ y.o & 19 & 47.5 \\
& $31-40$ y.o & 15 & 37.5 \\
\multirow{4}{*}{ Sex } & $41-50$ y.o & 3 & 7.5 \\
& $51-60$ y.o & 1 & 2.5 \\
& Male & 36 & 90 \\
\multirow{4}{*}{ Education } & Female & 4 & 10 \\
& Elementary & 1 & 2.5 \\
& Junior High & 4 & 10 \\
& Senior High & 30 & 75 \\
& University & 5 & 12.5 \\
\hline
\end{tabular}

Table 3 showed that difference between before and after giving treatment TLC levels were 2.7 $\mathrm{mm}^{3}$. The difference between before and after giving treatment albumin levels is $0.3 \mathrm{gr} / \mathrm{dL}$. The difference between before treatment and after treatment, CD4 levels were 47.6 cells $/ \mathrm{mL}$. The difference between before and after giving treatment clinical manifestations is 1.4. The difference between before and after giving BMI treatment was $0.3 \mathrm{~kg} / \mathrm{m}^{2}$.

When viewed by category, the BMI variable changed from being thin (BMI <18.5) before giving treatment by 11 people $(27.5 \%)$ to 9 people (22.5\%) after giving treatment. While CD4 variable, PLHIV also experienced changes, where the category $<200$ cells $/ \mathrm{mL}$ was 11 people $(27.5 \%)$ to 8 people $(20 \%)$. The distribution of BMI and CD4 changes before and after treatment can be seen in table 4.

There was a significant difference before and after treatment $(p<0.05)$ meaning that treatment of snakehead fish nugget and colored fruit juice will give effect on TLC levels albumin, CD4, clinical manifestations and BMI. Nugget is a popular snack variation to eliminate hunger for a while, provides a small supply of energy to the body, or something to eat enjoying the taste and would be better if consumed with colored juice. The snack

Table 3. Distribution of TLC, Albumin, CD4, Clinical Manifestation and BMI

\begin{tabular}{|c|c|c|c|c|c|c|c|}
\hline \multicolumn{2}{|c|}{ Indicators } & \multirow{2}{*}{$\begin{array}{c}\mathbf{n} \\
40\end{array}$} & \multirow{2}{*}{$\frac{\text { Min }}{9}$} & \multirow{2}{*}{$\begin{array}{c}\text { Max } \\
54\end{array}$} & \multirow{2}{*}{$\frac{\text { Mean }}{32.2}$} & \multirow{2}{*}{$\begin{array}{c}\text { Deviation Std. } \\
10.8\end{array}$} & \multirow{3}{*}{$\begin{array}{c}\text { p value } \\
0.016\end{array}$} \\
\hline TI C J Jvel & Before & & & & & & \\
\hline & After & 40 & 19 & 59 & 34.9 & 8.8 & \\
\hline \multirow{2}{*}{ Albumin Level } & Before & 40 & 2.7 & 5.1 & 4.1 & 0.4 & \multirow{2}{*}{0.009} \\
\hline & After & 40 & 2.1 & 5.0 & 4.4 & 0.5 & \\
\hline \multirow{2}{*}{ CD4 level } & Before & 40 & 18 & 750 & 315.3 & 169.3 & \multirow{2}{*}{$0.001 *$} \\
\hline & After & 40 & 8 & 856 & 362.9 & 183.2 & \\
\hline \multirow{2}{*}{$\begin{array}{l}\text { Clinical } \\
\text { Manifestation }\end{array}$} & Before & 40 & 3 & 14 & 5.45 & 2.3 & \multirow{2}{*}{$0.001 *$} \\
\hline & After & 40 & 2 & 14 & 4.05 & 2.5 & \\
\hline \multirow{2}{*}{ BMI } & Before & 40 & 13.6 & 29.5 & 21.2 & 3.9 & \multirow{2}{*}{0.008} \\
\hline & After & 40 & 13.4 & 30 & 21.5 & 4.0 & \\
\hline
\end{tabular}

Table 4. Distribution of Changes in BMI and CD4 Before and After Giving Treatment

\begin{tabular}{|c|c|c|c|c|c|c|c|c|c|c|c|c|c|}
\hline \multirow{3}{*}{ No } & \multirow{3}{*}{ Treatment } & \multicolumn{4}{|c|}{ BMI $\left(\mathrm{kg} / \mathrm{m}^{2}\right)$} & \multirow{2}{*}{\multicolumn{2}{|c|}{ Total }} & \multicolumn{4}{|c|}{ CD4 (sel/mL) } & \multirow{2}{*}{\multicolumn{2}{|c|}{ Total }} \\
\hline & & \multicolumn{2}{|c|}{ Wasting } & \multicolumn{2}{|c|}{ Normal } & & & \multicolumn{2}{|c|}{$<200$} & \multicolumn{2}{|c|}{$\geq 200$} & & \\
\hline & & $\mathbf{n}$ & $\%$ & $\mathrm{n}$ & $\%$ & $\mathbf{n}$ & $\%$ & $\mathbf{n}$ & $\%$ & n & $\%$ & $\mathbf{N}$ & $\%$ \\
\hline & Before & 11 & 27.5 & 29 & 72.5 & 40 & 100 & 11 & 27.5 & 29 & 72.5 & 40 & 100 \\
\hline & After & 9 & 22.5 & 31 & 77.5 & 40 & 100 & 8 & 20 & 32 & 80 & 40 & 100 \\
\hline
\end{tabular}


that was used as treatment contain $198.7 \mathrm{kcal}$ of energy, $12.8 \mathrm{~g}$ of protein, $3.25 \mathrm{~g}$ of fat, $25.1 \mathrm{~g}$ of carbohydrates, $29.2 \mathrm{mg}$ of zinc, $331.5 \mathrm{mg}$ of iron and bioactive substance as functional food. This snack is given in the form of snakehead fish nugget and colored fruit juice which have tendency to increase TLC, albumin, CD4 value, clinical manifestation, nutrient intake and body mass index value which tends to decrease in people with HIV at HIV/AIDS Rehabilitation Center in Medan.

Research by Pettalolo (2015) stated that there was an increase in the number of lymphocyte, CD4 and leucocyte in snakehead fish extract group with mineral content of zinc which can affect immune function, as well as being useful in restoring immunity function by influencing the activity of catalase enzyme and superoxide dismutase (SOD) and increase lymphokine production, so that leukocyte cells are able to differentiate and proliferate. While Warouw study (2016) stated that snakehead fish and red beans contain essential amino acids that can increase CD4 cytokine levels. Great number of CD4 count in PLHIV people is a predictor of decreasing clinical symptom.

Treatment of snakehead fish nuggets and colored fruit juices containing necessary to fulfill macronutrient and micronutrient to PLHIV. Snakehead fish contain protein that needed by body to build and maintain body tissues and replace damaged cells. Protein also protect body from foreign substance or organism that enter body. Protein act as antibody-forming component in the body. With fulfillment of protein needs, the formation of antibody will be more optimal and more protective, so body can defend itself from disease, such as HIV. The more adequate protein intake, the higher formation of body tissue and muscle, which can be seen from changes in BMI value (Kartasapoetra, 2011; Petalolo, 2015).

Snakehead fish nugget contain high albumin that help metabolism and replace damage tissue because of HIV. The other role of Albumin in HIV case is to help increasing metabolic rate of $\mathrm{Zn}$ and binding to drugs and heavy metal that do not dissolve easily in blood. Albumin is also able to work as trapper and scavenger against oxidant and free radical and able to improve immune function (Awan, 2014).

Albumin is suitable to be given to patients who were not experienced severe infections, such as respondent in this study that did not examine people with AIDS. Determination of PLHIV severity is not only determined by CD4 levels in the blood, but it can be seen from clinical symptom and opportunistic infection that accompanying PLHIV, where there are no symptoms such as anorexia, the appearance of candida in the mouth, prolonged diarrhea and PLHIV do not have tuberculosis and herpes simplex (PUSDIKLAT NAKES, 2014).

This is also in accordance with the criteria for patients admitted to the center, especially people who are newly infected with HIV (PLHIV). The increase in albumin level in PLHIV patient is expected to help the process where HIV-infected people are susceptible to an increase in catabolic responses (Pettalolo, 2015). With the increase in albumin levels after distribution of snakehead fish albumin, the body will create a new balance by reducing tissue protein intake, so that the depletion process (tissue remodeling) that often occurs when people newly infected with HIV can be stopped by giving albumin (Hartono, 2002). Research by Wahyuni (2014) at dr. Iskak Tulungagung hospital showed that as many as $85 \%$ of postoperative patients with hypoalbumin experienced an increase in albumin levels after being given snakehead fish extract for 7 consecutive days.

In this study, snakehead fish nuggets was given together with colored fruit juice containing vitamin C, lycopene, anthocyanin, flavonoid, karetonoid, beta-carotene, bromelain, papain and quercetin, which come from natural ingredient. Vitamin $\mathrm{C}$ in colored fruit juice have function as antioxidant that suppress cell damage due to infection, help to stop the process of cell destruction, also act as anti-inflammatory (Puertollano et al., 2011; Almatsier, 2016). In conditions of prolonged fever that generally occur in people infected with HIV, bioactive substance and vitamin $\mathrm{C}$ also function to regulate lymphocyte formation and transport lymphocyte to the site of infection (Arifin, 2009).

The effectiveness of snakehead fish extract should be combined with drink containing vitamin $C$ sourced from natural ingredient that can be obtained from fruit content because it contain bioactive substance such as flavonoid, karetonoid, anthocyanin, papain, bromelain, and quercetin. These substance can be found in watermelon, 
orange, mango, star fruit, red guava, pineapple, carrots, dragon fruit, papaya, cucumber, tomato, passion fruit, and tamarillo. These substance can help recovery from infection because of its benefits that play role in protecting cell and tissue against damage. Meanwhile, enzyme content of bromelain in pineapple juice has potential as alternative treatments to reduce the symptom such as sore and throbbing pain in PLHIV (Winarti, 2017).

Snakehead fish nugget have higher zinc due to the addition of red bean which are also high in zinc. Zinc is a metal that effectively bound albumin that has function to increase the effectiveness of $\mathrm{T}$ and $\mathrm{B}$ lymphocytes function. In addition, zinc is also able to close wounds and reduce inflammatory reaction in tissues caused by HIV virus. (Noviyanti, 2010; Candra, 2018). The role of zinc from snakehead and red bean nugget will have effect if combined with vitamin $\mathrm{C}$ which comes from colored fruit juice, where vitamin $\mathrm{C}$ acts as an antioxidant and increases immunity so that PLHIV do not get sick easily and catabolic processes that can reduce BMI do not occur (Warouw et al., 2016). The content of bioactive substances in fruits can work as proteolytic, also destroy HIV virus horn made of protein. Bioactive substance (papain, bromolain, anthocyanin, lycopene, etc.) can damage protein wall of HIV virus so that $\mathrm{T}$ helper lymphocytes and CD4 do not experience destruction due to HIV infection (Wardani, 2016).

\section{CONCLUSIONS}

The provision of 100 grams snakehead fish nuggets and $250 \mathrm{~mL}$ colored fruit juices a day for 24 days improve clinical manifestation, BMI, TLC and CD4 level with $p$ value $<0.05$. It is necessary to provide treatment in longer term as a preventive measure for the emergence of various clinical manifestation and to increase TLC, CD4 and BMI in PLHIV at HIV/AIDS Rehabilitation Center in Medan.

\section{REFERENCES}

Adiningsih, S. \& Wirna, W. (2017). Resiko malnutrisi terhadap jumlah CD4 orang dengan HIV/AIDS yang menjalani terapi antiretroviral di Miminka. Jurnal Kedokteran Brawijaya. 30(1): 41-46. Doi 10.21776/ub.jkb.2018.030.01.8
Almatsier, S. (2016). Prinsip dasar ilmu gizi. Jakarta: PT Gramedia Pustaka Utama.

Almatsier, S. (2018). Penuntun diet. Jakarta: PT Gramedia Pustaka Utama.

Anderson, K. (2017) Hubungan Status Gizi dengan Kualitas Hidup Orang dengan HIV/AIDS di Semarang. Jurnal Kedokteran Diponegoro, April 2017:692-704. Doi: dmj.v6i2.18587

Arifin H. (2009). Peranan glutamin. Majalah Kedokteran Nusantara; 42(1):66-71 retrieved from: https://jurnal.ugm.ac.id/jgki

Astuti, N.,Awan, S.A. (2014). Manfaat Suplementasi Ekstrak Ikan Gabus terhadap Kadar Albumin, MDA pada Luka Bakar Derajat II. JST Kesehatan, Oktober 2014: 385-393.

Brennan, T.A. (2019). Growth Curve Modelling to Determine Distinct Body Mass Index Trajectory Groups in HIV-Positive Adults on ART in South Africa. Jurnal AIDS 2019 November 01;33(13):2049-2059. doi: 10.1097/ QAD.0000000000002302

Candra, A. (2018). Suplementasi Seng untuk Pencegahan Penyakit Infeksi. JNH: Journal of Nutrition and Healthy. 6(1): 31-36. Doi: jnh.6.1.2018.31-36.

Emuchay, I.C. (2014) Correlation Between Total Lymphocyte Count, Hemoglobin, Hematocrit and CD4 Count in HIV Patients in Nigeria. Pakistan Journal of Biological Sciences, doi: 10.3923/pjbs.

Fitri, A.S., Djatnika, S., \& Herry, G. (2013). Korelasi Total Lymphocyte Count terhadap CD4 anak dengan Infeksi Human Immundeficiency Virus. Departemen Ilmu Kesehatan Anak FK UNPAD. 15 (2).

Hartono, A. (2014). Terapi Gizi dan Diet Rumah Sakit. Jakarta: Penerbit EGC.

Kementrian Kesehatan RI. (2010). Pedoman Pelayanan Gizi Bagi ODHA 2010 . Jakarta: KEMENKES RI.

Negara, K.N.D.P., Ari, W. \& Susy, P. (2015). Relationship Between Body Mass Index (BMI) Overweight and Obes Categories With Low Back Pain (LBP) Complaints Among Medical Faculty Students of Udayana University. Majalah Ilmiah Fisioterapi Indonesia, Vol 3. Doi: 10.24843/MIFI.2015.v03.i03.p01.

Pettalolo, S.R. (2015). Efek Suplementasi Ekstrak Ikan Gabus dan Vitamin C Terhadap Kadar Hemoglobin, Leukosit, Limfosit, Albumin, dan IMT pada Pasien HIV/AIDS. Gizi Indonesia. Doi: 10.36457/gizindo.v38i1.166. 
Puertollano, M., Puertallano, E., Cienfuegos, G., \& Pablo, M. (2011). Dietary Antioxidants: Immunity and Host Defense. Curr Top Med Chem. 2011;11(14):1752-66.

Pusdiklat Nakes. (2014). Modul Pelatihan Manajemen HIV-AIDS Bagi Tenaga Pendidik.

Prastowo, A., Wiriyatun, L., Siti, N., \& Retno, S. (2016). Efektifitas Pemberian Ekstra Putih Telur terhadap Peningkatan Kadar Albumin dan IL-6 pada Pasien Tuberkulosis dengan Hipoalbumin. Jurnal Kesehatan. Vol 1. No 1. doi: 10.23917/ jk.v9i1.3373.

Rachmat, M. (2015). Metodologi Penelitian Gizi dan Kesehatan. Jakarta: Penerbit Buku Kedokteran.

Restiana, T. \& Bukhari. (2011). Pengaruh Pemberian Ekstrak Ikan Gabus Terhadap Kadar Albumin dan Status Gizi Penderita HIV/AIDS yang mendapatkan Terapi ARV. FK Universitas Hasanuddin. Makassar.

Riyadi H \& Widodo S. (2015). Perbaikan Status Gizi Anak Balita dengan Intervensi Biskuit Berbasis Blondo, Ikan Gabus (Channa Striata), dan Beras Merah (Oryza Nivara). Jurnal Gizi Pangan, Juli 2015, 10(2):85-92. Doi: 10.25182/ jgp.2015.10.2.\%p.

Supariasa I,D.N. (2016). Penilaian Status Gizi. Jakarta: ECG.

Wahyuni, S., Yuly, P., Sandu, S. (2014). Pengaruh Pemberian (Albumin) Ikan Kutuk Terhadap Peningkatan Kadar Albumin Pada Pasien
Post Operasi Hipoalbumin RSUD dr.Iskak Tulungagung. 1-9.

Wahyuningsih, U., Ali, K., \& Karina, R.E. (2014). Asupan Zat Gizi dan Status Anemia pada Remaja Laki-laki Pengguna Narkoba di Lembaga Permasyarakatan Anak Pria Tangerang. Jurnal Gizi dan Pangan, 9(1).Doi: 10.25182/jgp.2014.9.1.\%p.

Wardhani, P. \& Nurbani. (2016). Efektifitas pemberian jus nanas dan jus pepaya sebagai pendamping ARV dalam meningkatkan kadar CD. Jurnal vokasi kesehatan, Vol II 1 Januari 2016, hlm 78-83. Doi: 10.30602/jvk.v2i1.59.

Warouw, H, N., As'ad, S., Hatta, M., Hadju, V. (2016). The Effect of Snakehead Fish Extract Supplements to the Enhancement of Nutritional Status, Level of Albumin, Hemoglobin and Level of CD4 on Pregnant Women with HIV AIDS Who Acquired Antiretroviral Therapy in Papua. International JournalofSciences : Basic and Applied Research (IJSBAR). 30(04): 384-397. Retrieved from: http:// gssrr.org/ index.php?journal=JournalOfBasic And Applied.

Winarti, Sri. (2017). Makanan Fungsional. Yogyakarta: Graha Ilmu.

Yuniarti. (2013). Pengaruh Konseling Gizi dan Penambahan Makanan Terhadap Asupan Zat Gizi dan Status Gizi Pasien HIV/AIDS. Jurnal Gizi Klinik Indonesia, Januari 2013:132-138. doi: $10.22146 /$ ijen. 15446. 